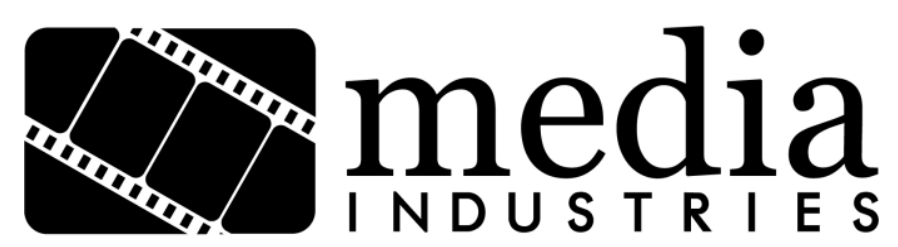

\title{
Film Studies, Cultural Studies, and Media Industries Studies
}

\section{Thomas Schatz 1}

The University of Texas at Austin

tschatz [AT] austin.utexas.edu

\begin{abstract}
:
This thought piece contends that the aesthetic, humanistic, and cultural concerns that fueled the rise of film studies and cultural studies should remain central to the burgeoning field of media industries studies - alongside issues of ownership, commerce, and control. Chief among these are questions of authorship, innovation, and mode of production, which remain vital emphases in both film and television studies, as evidenced by the current work being done on indie film auteurs and television series showrunners, albeit along very different theoretical and analytical lines. Media Industries provides an ideal forum for pursuing such work, and for considering the fundamentally different conceptions of authorship in film and television studies as well - differences which, in terms of media industry practice, are rapidly blurring in the current age of convergence and conglomeration.
\end{abstract}

Keywords: Film, Television, Authorship, Production

I'll begin with an anecdote. A few years back, I contributed an essay on Hollywood history to the collection Media Industries: History, Theory, and Method. ${ }^{2}$ When I submitted the piece, coeditor Jennifer Holt mentioned that she was delighted to have something that dealt with authorship and film style. I thought that a bit odd at the time, but when the book was published I understood what she meant. While I was pleased to be included in that excellent collection, the volume as a whole had little to say-remarkably little, it seemed to me-about individual agency in the creation of media content, about the formal style and expressive qualities of individual works, and about the analysis and assessment of media texts. I immediately flashed back to that moment of realization when I was invited to write this brief reflection on media industries research. I find myself asking whether the issues that were so crucial to the emergence of film studies back in the 1960s and '70s are of central importance, or of any real importance at all, to the burgeoning field of media industries studies.

The centrality of these questions to film studies a half century ago was the result of conditions in both the film industry and the academy. American cinema and indeed world cinema were then in the throes of profound change, with the rise of national movements like the French New Wave and New German Cinema; the prominence of international auteurs like Bergman, Fellini, 
and Kurosawa; and the surprising emergence of the Hollywood renaissance. Cinema suddenly was being taken seriously as an art form as well as a social and cultural phenomenon, particularly by a new generation of critics - Andrew Sarris, Pauline Kael, et al. - and by a new generation of scholars in the arts and humanities programs where film studies first took hold. For these critics and scholars, individual artists and great works were the coin of the realm, and thus their preoccupation with auteurism and canon formation. Meanwhile, on another academic front, the truly explosive impact of structuralism and semiotics had scholars and intellectuals radically rethinking the very notion of culture and reassessing the once reviled "culture industries." This laid the groundwork for cultural studies, which coalesced during the 1970s in close confluence with film studies in the US and UK.

Both the industrial and academic landscapes have changed considerably since then. The prospect of a "directors' cinema" in the US or anywhere else has become increasingly remote since the 1970s, as have the modernist and art-cinema impulses that fueled that unique, exceptional era. The critical and theoretical agendas evolved as well, due largely to industry changes but also to more complex approaches by film scholars (if not critics and journalists) to questions of authorship, aesthetics, and the production of culture. These issues still fuel film studies, obviously enough. But whether (and how) they pertain to media industries studies remains to be seen-and remains, for me, a crucial issue. It seems to me imperative that we keep in mind the fact that the media industries are cultural industries involving the systematic production and consumption of expressive, meaningful works that manifest our shared sense of ourselves, our lives, our values. We who study the media are obliged to examine the industrial process, with its necessary compulsion for standardization and commodification. But we are also obliged to identify and account for instances of disruption and innovation, the differences that truly make a difference in the industrial production of culture.

As the study of media industries develops, I cannot help but notice a decided slant toward a political economy approach - analyses that focus on ownership and control, on technology and policy, on marketing and consumption, with only incidental concern for the creative and cultural dynamics involved. I do not wish to rehash the political economy versus cultural studies debate. On the contrary, media industries studies demands that we integrate these two vital and complementary (if seemingly contrary) ways of seeing and assessing the media. It demands that we consider not only media ownership but also the means and modes of production as well as the products themselves. It demands that we examine the mainstream and the margins of media production and consumption, trying to understand and assess a broad range of expressive, meaningful work. It demands that we ask what constitutes authorship in the context of cultural production, and what creative and administrative work roles really matter in the production process. We must ask whether the industrial machinery functions to facilitate, enable, or even allow for individual human agency, let alone personal expression. Under what circumstance, and to what ends, do the media industries promote (pun intended) the individual author? Has the very notion of authorship in contemporary mediamaking become little more than a discursive construction, a necessary journalistic fiction, and a marketing ploy?

These questions of creativity, commerce, and cultural production are cogently addressed in a recent essay in Critical Studies in Media Communication, "Culture Industries in a Postindustrial Age: Entertainment, Leisure, Creativity, Design," by Raúl Rodríguez-Ferrándiz. ${ }^{3}$ As his title suggests, Rodríguez-Ferrándiz advocates a return to the Frankfurt School's original term culture industries. The label dates back to the 1940s, of course, to Adorno and Horkheimer's devastating 
critique of mass media and mass culture. ${ }^{4}$ But as Rodríguez-Ferrándiz points out, our view of culture and its systematic (re)production has been recast and rehabilitated by Umberto Eco, Stuart Hall, John Fiske, Pierre Bourdieu, and other scholars. From their more nuanced perspective, "Consumption in general and its most eminent form, the consumption of culture, constituted an arena for a genuine construction of meaning, or at the very least, for a reappropriation for purposes that could not be anticipated, rather than a mere displaying of the meanings which had been craftily placed there by the producers of culture." 5

Rodríguez-Ferrándiz prefers the term culture industries to other current labels-entertainment industries, leisure industries, and particularly, creative industries. The latter is widely used in Europe and Australia, he notes, and tends to dominate the discussions (and policy legislation) related to cultural production. In the process, the very concept of "creative work" has been diluted of all nuance and precision: "We have passed from the anguish and disappointment Adorno felt on seeing the creative act of the artist swallowed up by the logic of industry, to qualifying the entire industry as 'creative,' to place creativity itself at the very heart of this industry."6 Rodríguez-Ferrándiz does not include media industries in his inventory of labels, although he acknowledges "the communicative explosion of all industrial production in a media environment." 7 This is scarcely an oversight, since he is considering industries like fashion design and the performing arts that do not involve media in their delivery and consumption. But clearly the study of media industries falls within his general purview and is subject to the same essential questions about the "genuine construction of meaning" and the tendency simply to take for granted-and thus, ultimately, to overlook - the creative practices and protocols involved.

With the media industries expanding and cross-pollinating at a furious pace, these questions of innovation and authorship have never been more acute, and in fact a good many film and television scholars are addressing them. Consider the work being done in television studies on cable series programming and the role of the showrunner, for instance, and the ongoing wrangle in film studies over the indie movement and the role of the indie auteur. But significantly enough, particularly for my purposes here, it's worth noting that this work is being done in very separate scholarly quarters, and for the most part outside the media industries studies arena as well. ${ }^{8}$ This seems shortsighted and rather ironic for several reasons. One is that the emerging media industries studies field itself owes such an obvious debt to breakthrough authorship studies in the 1980s - Tino Balio's two-volume history of United Artists, for instance, and the work by Jane Feuer, et al., on MTM Enterprises and "quality television." 9 A second is that the scholarly work both on showrunners and on indie auteurs is so clearly attuned to the industrial milieu in which these content creators are operating. And yet a third reason is that industry conditions in the convergent, conglomerate era are actively compelling the migration of top talent between the film and television sectors - in both directions, in fact, and at a dizzying rate.

Media Industries provides a venue in which these developments can and should be assessed, along with the larger theoretical issues involving the entrenched and very different conceptions of individual agency and authorship in film and television studies. Film scholars continue to focus authorship studies on the director, a work role that is rarely even mentioned, let alone seriously considered, in discussions of TV series authorship. Television scholars, meanwhile, tend to gauge authorship in terms of the producer or the writer - or both in the case of the showrunner, who invariably rose through the writers' ranks to a management role, and who oversees the series as an executive producer while directly supervising the writing staff. These 
very different views of authorship are a function of the distinct modes of production involved, although these distinctions are rapidly blurring under current industry conditions. What are we to make, for example, of Lena Dunham, who reworked a modest indie film-festival hit into an auteur-driven HBO series (Girls, 2012-), and who did so as a multi-hyphenate, twentysomething female-an unthinkable achievement in the retrograde movie industry? Or True Detective (2014-), perhaps the single best example to date of cable television's-and particularly HBO's - appropriation of the indie film ethos on both sides of the camera? Or J.J. Abrams and the billion-dollar reboot of Paramount's primordial Star Trek franchise?

The list goes on and on, and spans a widening array of media industries, each with its own regimes of production and expression. As the forces of convergence and conglomeration bring these industries - and these regimes - into closer accord, issues of production and expression become ever more important and more complex. Indeed, the challenges posed when dealing with adjacent industries like film and television seem rather modest once we begin to factor, say, the gaming and software industries into the equation. But as the established culture industries evolve and as new industries coalesce, the same core questions pertain. How do these industries systematically create both capital and culture? How do they value standardization and innovation in the production and consumption of media content? What work is required to produce that content, and which work roles-and which workers-are privileged in that process? Questions of ownership and control pertain as well, of course, but these should be considered alongside-and in dynamic interaction with-those that address the expressive power and appeal of culture industry products.

1 Thomas Schatz is Professor of Film and Media Studies in the Radio-Television-Film Department at the University of Texas at Austin. He has written four books (and edited many others) about Hollywood films and filmmaking, including Hollywood Genres (New York: McGraw-Hill, 1981); Boom and Bust: American Cinema in the 1940s (Berkeley: University of California Press, 1999); and The Genius of the System: Hollywood Filmmaking in the Studio Era (Minneapolis: University of Minnesota Press, 2010).

2 Jennifer Holt and Alisa Perren, eds., Media Industries: History, Theory, and Method (Malden, MA: Wiley-Blackwell, 2009).

3 Raúl Rodríguez-Ferrándiz, "Culture Industries in a Postindustrial Age: Entertainment, Leisure, Creativity, Design," Critical Studies in Media Communication (2013): 1-15, accessed October 20, 2013, doi:org/10.1080/15295036.2013.840388

4 Horkheimer, Max, and Theodor W. Adorno. Dialectic of Enlightenment: Philosophical Fragments. (Stanford, CA: Stanford University Press, 2002).

5 Rodríguez-Ferrándiz, " "Culture Industries in a Postindustrial Age," 2.

6 Ibid., 11.

7 Ibid., 1.

8 There are as few exceptions here, particularly among recent books on the indie film movement that focus on individual and corporate authorship within an industrial context. These include Geoff King, Indiewood USA: Where Hollywood Meets Independent Cinema (London: Tauris, 2009); Yannis Tzioumakis, Hollywood's Indies: Classics Division, Specialty Labels, and American Independent Cinema (Edinburgh: Edinburgh University Press, 2012); and Alisa Perren, Indie, Inc.: Miramax and the Transformation of Hollywood in the 1990s (Austin: University of Texas Press, 2013). 
9 Tino Balio, United Artists, Volume 1, 1919-1950: The Company Built by the Stars (Madison: University of Wisconsin Press, 2009); Tino Balio, United Artists, Volume 2, 1951-1978: The Company That Changed the Film Industry (Madison: University of Wisconsin Press, 2009); Jane Feuer, Paul Kerr, and Tise Vahimagi, eds., MTM 'Quality Television' (London: British Film Institute, 1985).

\section{Bibliography}

Balio, Tino. United Artists, Volume 1, 1919-1950: The Company Built by the Stars. Madison: University of Wisconsin Press, 2009.

Balio, Tino. United Artists, Volume 2, 1951-1978: The Company That Changed the Film Industry. Madison: University of Wisconsin Press, 2009.

Feuer, Jane, Paul Kerr, and Tise Vahimagi, eds. MTM 'Quality Television.' London: British Film Institute, 1985.

Holt, Jennifer, and Alisa Perren, eds. Media Industries: History, Theory, and Method. Malden, MA: Wiley-Blackwell, 2009.

Horkheimer, Max, and Theodor W. Adorno. Dialectic of Enlightenment: Philosophical Fragments. Stanford, CA: Stanford University Press, 2002.

King, Geoff. Indiewood USA: Where Hollywood Meets Independent Cinema. London: Tauris, 2009.

Perren, Alisa. Indie, Inc.: Miramax and the Transformation of Hollywood in the 1990s. Austin: University of Texas Press, 2013.

Rodríguez-Ferrándiz, Raúl. "Culture Industries in a Postindustrial Age: Entertainment, Leisure, Creativity, Design." Critical Studies in Media Communication (2013): 1-15.

Tzioumakis, Yannis. Hollywood's Indies: Classics Division, Specialty Labels, and American Independent Cinema. Edinburgh: Edinburgh University Press, 2012.

\section{(cc) BY-NC-ND}

Copyright (C) 2014 (Thomas Schatz). Media Industries is an open-access, peer-reviewed, online academic journal. As such, we aim to participate in the open exchange of information. This work is licensed under a Creative Commons Attribution Noncommercial No Derivatives (by-nc-nd) License. Under this license, this work is available for sharing and noncommercial distribution provided the appropriate attribution is given. 